\title{
Atmospheric $\mathrm{H}_{2} \mathrm{~S}$ exposure does not affect stomatal aperture in maize
}

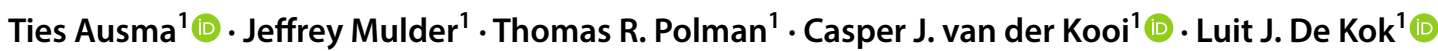

Received: 23 July 2020 / Accepted: 12 September 2020 / Published online: 24 September 2020

(c) The Author(s) 2020

\begin{abstract}
Main conclusion Stomatal aperture in maize is not affected by exposure to a subtoxic concentration of atmospheric $\mathrm{H}_{2} \mathrm{~S}$. At least in maize, $\mathrm{H}_{2} \mathrm{~S}$, thus, is not a gaseous signal molecule that controls stomatal aperture.

Abstract Sulfur is an indispensable element for the physiological functioning of plants with hydrogen sulfide $\left(\mathrm{H}_{2} \mathrm{~S}\right)$ potentially acting as gasotransmitter in the regulation of stomatal aperture. It is often assumed that $\mathrm{H}_{2} \mathrm{~S}$ is metabolized into cysteine to stimulate stomatal closure. To study the significance of $\mathrm{H}_{2} \mathrm{~S}$ for the regulation of stomatal closure, maize was exposed to a subtoxic atmospheric $\mathrm{H}_{2} \mathrm{~S}$ level in the presence or absence of a sulfate supply to the root. Similar to other plants, maize could use $\mathrm{H}_{2} \mathrm{~S}$ as a sulfur source for growth. Whereas sulfate-deprived plants had a lower biomass than sulfate-sufficient plants, exposure to $\mathrm{H}_{2} \mathrm{~S}$ alleviated this growth reduction. Shoot sulfate, glutathione, and cysteine levels were significantly higher in $\mathrm{H}_{2} \mathrm{~S}$-fumigated plants compared to non-fumigated plants. Nevertheless, this was not associated with changes in the leaf area, stomatal density, stomatal resistance, and transpiration rate of plants, meaning that $\mathrm{H}_{2} \mathrm{~S}$ exposure did not affect the transpiration rate per stoma. Hence, it did not affect stomatal aperture, indicating that, at least in maize, $\mathrm{H}_{2} \mathrm{~S}$ is not a gaseous signal molecule controlling this aperture.
\end{abstract}

Keywords Stomata $\cdot$ Transpiration $\cdot$ Signal molecule $\cdot$ Gasotransmitter $\cdot$ Sulfur metabolism $\cdot$ Air pollution

\section{Introduction}

Sulfur is an essential macronutrient for plants, which plants usually acquire as sulfate via the root (Hawkesford and De Kok 2006). After its uptake, sulfate is reduced via several intermediates to sulfide, which is subsequently incorporated in cysteine via the reaction of sulfide with $O$-acetylserine (OAS), catalyzed by the enzyme $O$-acetylserine(thiol)lyase (OAS-TL; Hawkesford and De Kok 2006). Cysteine functions as the precursor and reduced sulfur donor for the synthesis of other organic compounds.

Communicated by Anastasios Melis.

Electronic supplementary material The online version of this article (https://doi.org/10.1007/s00425-020-03463-6) contains supplementary material, which is available to authorized users.

Ties Ausma

t.ausma@rug.nl

1 Laboratory of Plant Physiology, Groningen Institute for Evolutionary Life Sciences, University of Groningen, Groningen, The Netherlands
It is often assumed that sulfur-containing metabolites might modulate physiological processes in plants. Hydrogen sulfide $\left(\mathrm{H}_{2} \mathrm{~S}\right)$ might act as endogenous gasotransmitter that affects plant development and stress tolerance (Sirko and Gotor 2007; Calderwood and Kopriva 2014; Maniou et al. 2014; Hancock 2018). Moreover, $\mathrm{H}_{2} \mathrm{~S}$ might control the aperture of stomata (Lisjak et al. 2010, 2011; Scuffi et al. 2014; Honda et al. 2015; Li et al. 2016; Aroca et al. 2018; Zhang et al. 2019). It is assumed that $\mathrm{H}_{2} \mathrm{~S}$ is metabolized into cysteine to stimulate the synthesis of abscisic acid (ABA), which is the canonical trigger for stomatal closure (Batool et al. 2018; Rajab et al. 2019).

The physiological significance of $\mathrm{H}_{2} \mathrm{~S}$ for stomatal closure should, however, be questioned. Research with thale cress (Arabidopsis thaliana), maize (Zea mays), cabbage (Brassica olerecea), pumpkin (Curcubita pepo), spruce (Picea abies), and spinach (Spinacea oleracea) showed that exposure to atmospheric $\mathrm{H}_{2} \mathrm{~S}$ did not affect transpiration rates, measured at the whole plant level, at various concentrations and under all exposure periods applied (which ranged from minutes to days; De Kok et al. 1989; Van der Kooij and De Kok 1998; Stuiver and De Kok 2001; Tausz et al. 1998). 
Accordingly, there are at least two caveats pertaining studies that reported impacts of $\mathrm{H}_{2} \mathrm{~S}$ on stomatal dynamics. First, uncontrolled, potentially very high, levels of $\mathrm{H}_{2} \mathrm{~S}$ have been used (e.g., Scuffi et al. 2014; Zhang et al. 2019). Sodium hydrosulfide (NaHS) has been used as $\mathrm{H}_{2} \mathrm{~S}$ donor and it was added to nutrient or tissue incubation solutions at $\mathrm{pH}<7.0$. However, if $\mathrm{NaHS}$ is used at this $\mathrm{pH}$ range, $\mathrm{HS}^{-}$is rapidly converted to gaseous $\mathrm{H}_{2} \mathrm{~S}$ ( $\mathrm{HS}^{-}+\mathrm{H}^{+} \rightleftarrows \mathrm{H}_{2} \mathrm{~S}$; $\mathrm{pKa}=7.0$; Lee et al. 2011). Since $\mathrm{H}_{2} \mathrm{~S}$ is rather poorly soluble in water (the Henry's law solubility constant for $\mathrm{H}_{2} \mathrm{~S}$ is $0.086 \mathrm{M} \mathrm{atm}^{-1}$ at $25^{\circ} \mathrm{C}$ ), it is quickly released into the atmosphere, where it may transiently reach phytotoxic (growth-inhibiting) levels (Lee et al. 2011; Riahi and Rowley 2014). $\mathrm{H}_{2} \mathrm{~S}$ may bind to metallo-groups in enzymes and other proteins (Beauchamp et al. 1984; Maas and De Kok 1988). Reported impacts of $\mathrm{H}_{2} \mathrm{~S}$ on stomatal aperture could possibly be the consequence of such toxicity, instead of being specifically related to $\mathrm{H}_{2} \mathrm{~S}$ functioning as gasotransmitter. One should further bear in mind that especially thale cress, which functioned as model plant, is rather susceptible to atmospheric $\mathrm{H}_{2} \mathrm{~S}$ (Van der Kooij and De Kok 1998; Birke et al. 2015).

Secondly, in some studies (e.g., Zhang et al. 2019), mutants with a modified $\mathrm{H}_{2} \mathrm{~S}$ homeostasis were used. Genetic manipulation of $\mathrm{H}_{2} \mathrm{~S}$ homeostasis may not only alter tissue $\mathrm{H}_{2} \mathrm{~S}$ content, but also the contents of other metabolites. These associated changes in metabolite contents may impact stomatal aperture. Hence, perceived impacts on stomatal aperture in mutants cannot directly be ascribed to the modification in $\mathrm{H}_{2} \mathrm{~S}$ homeostasis (viz., genotypic variation cannot directly be translated to phenotypic variation; Piersma and Van Gils 2011; Noble 2013; Noble et al. 2014).

The application of controlled, subtoxic (non-growthinhibiting) levels of atmospheric $\mathrm{H}_{2} \mathrm{~S}$ to non-mutant plants can provide a physiologically realistic view of the role of $\mathrm{H}_{2} \mathrm{~S}$ in stomatal regulation. Plants absorb atmospheric $\mathrm{H}_{2} \mathrm{~S}$ via stomata, since the leaf's cuticle is hardly permeable for gases (Ausma and De Kok 2019). At the pH of leaf cells (i.e., 5-6.4) absorbed $\mathrm{H}_{2} \mathrm{~S}$ remains largely undissociated, causing it to easily pass cellular and subcellular membranes (Lee et al. 2011; Riahi and Rowley 2014). Foliar $\mathrm{H}_{2} \mathrm{~S}$ levels increase significantly upon $\mathrm{H}_{2} \mathrm{~S}$ fumigation (Ausma and De Kok 2019). For instance, exposure of thale cress to 0.5 and $1.0 \mathrm{\mu l}^{-1} \mathrm{H}_{2} \mathrm{~S}$ enhanced leaf $\mathrm{H}_{2} \mathrm{~S}$ levels by approximately twofold and threefold, respectively (Birke et al. 2015). Since $\mathrm{H}_{2} \mathrm{~S}$ is rapidly and with high affinity metabolized in cysteine, $\mathrm{H}_{2} \mathrm{~S}$ fumigation also strongly enhanced foliar cysteine content and that of the tripeptide glutathione (De Kok et al. 1997; Birke et al. 2015; Ausma et al. 2017; Ausma and De Kok 2019). Thus, fumigation with low $\mathrm{H}_{2} \mathrm{~S}$ levels may profoundly alter tissue sulfur status, without affecting plant growth (Ausma and De Kok 2019).

Plants may switch from using sulfate to using $\mathrm{H}_{2} \mathrm{~S}$ as sulfur source: $\mathrm{H}_{2} \mathrm{~S}$ absorbance by the foliage may partially downregulate the uptake and subsequent metabolism of sulfate (Buchner et al. 2004; De Kok et al. 1997). Plants may even grow with atmospheric $\mathrm{H}_{2} \mathrm{~S}$ as the only sulfur source (viz., in the absence of a root sulfate supply; De Kok et al. 1997; Koralewska et al. 2007, 2008). Whereas sulfate deprivation may reduce plant growth rate as well as endogenous cysteine and glutathione levels, fumigation with a sufficiently high $\mathrm{H}_{2} \mathrm{~S}$ level may fully alleviate these reductions.

Here, we study the importance of $\mathrm{H}_{2} \mathrm{~S}$ as gaseous signal molecule for the regulation of stomatal aperture in maize (Zea mays). Initially, we determined the $\mathrm{H}_{2} \mathrm{~S}$ level that is subtoxic for maize, though sufficiently high to fully cover the plant's sulfur demand for growth (viz., the $\mathrm{H}_{2} \mathrm{~S}$ concentration at which $\mathrm{H}_{2} \mathrm{~S}$-fumigated plants have a similar biomass as non-fumigated sulfate-sufficient plants). We then exposed plants for several days to this atmospheric $\mathrm{H}_{2} \mathrm{~S}$ level in the presence or absence of a root sulfate supply. We measured plant growth, sulfur status, stomatal density, stomatal resistance, and transpiration rates. We conclude that, at least in maize, $\mathrm{H}_{2} \mathrm{~S}$ is not a gaseous signal molecule that controls stomatal opening.

\section{Materials and methods}

\section{Plant material and growth conditions}

Seeds of maize (Zea mays; cultivar number 669; Van Der Wal; Hoogeveen; The Netherlands) were germinated between moistened filter paper in the dark at $23{ }^{\circ} \mathrm{C}$. After 3 days, the seedlings were put on 151 boxes containing aerated tap water, which were placed in a climate-controlled room. Air temperature was $23^{\circ} \mathrm{C}\left( \pm 1{ }^{\circ} \mathrm{C}\right)$, relative humidity was $60-70 \%$, and the photoperiod was $16 \mathrm{~h}$ at a photon fluency rate of $300 \pm 20 \mu \mathrm{mol} \mathrm{m}^{-2} \mathrm{~s}^{-1}$ (within the $400-700 \mathrm{~nm}$ range) at plant height, supplied by Philips GreenPower LED (deep red/white 120) production modules.

After 7 days, the seedlings were transferred to 131 stainless-steel boxes ( 10 sets of plants per box, 6 plants per set in the first experiment, and 4 plants per set in the second experiment) holding aerated $50 \%$ Hoagland nutrient solutions, which were placed in 501 cylindrical stainless-steel cabinets (0.6 m diameter) with a polymethyl-methacrylate top (Supplementary Fig. S1). Day and night air temperatures were 21 and $18{ }^{\circ} \mathrm{C}\left( \pm 1^{\circ} \mathrm{C}\right)$, respectively, relative humidity was $30-40 \%$, and the photoperiod was $16 \mathrm{~h}$ at a photon fluency rate of $300 \pm 20 \mu \mathrm{mol} \mathrm{m} \mathrm{m}^{-2}$ (within the $400-700 \mathrm{~nm}$ range) at plant height, supplied by Philips GreenPower LED (deep red/white 120) production modules. Air exchange inside the cabinets was $401 \mathrm{~min}^{-1}$ and the air inside the cabinets was stirred continuously by a ventilator. Nutrient solutions either contained $1 \mathrm{mM}$ sulfate $(+\mathrm{S}$; sulfate-sufficient; solution's composition being $2.5 \mathrm{mM} \mathrm{CaCl}, 2.5 \mathrm{mM}$ $\mathrm{KCl}, 0.5 \mathrm{mM} \mathrm{KH} \mathrm{PO}_{4}, 1 \mathrm{mM} \mathrm{MgSO}{ }_{4}, 3.75 \mathrm{mM} \mathrm{NH}_{4} \mathrm{NO}_{3}$, 
$23.4 \mu \mathrm{M} \mathrm{H}_{3} \mathrm{BO}_{3}, 4.8 \mu \mathrm{M} \mathrm{MnCl}_{2}, 0.48 \mu \mathrm{M} \mathrm{ZnSO}_{4}, 0.16 \mu \mathrm{M}$ $\mathrm{CuSO}_{4}, 0.26 \mu \mathrm{M} \mathrm{Na}_{2} \mathrm{MoO}_{4}$ and $45 \mu \mathrm{M} \mathrm{Fe}^{3+}$ EDTA), or $0 \mathrm{mM}$ sulfate (-S; sulfate-deprived; all sulfate salts replaced by chloride salts).

Plants were fumigated either with $0,0.5,1.0$, or $1.5 \mathrm{\mu l}^{-1}$ $\mathrm{H}_{2} \mathrm{~S}$. Pressurized $\mathrm{H}_{2} \mathrm{~S}$ diluted with $\mathrm{N}_{2}\left(1.0 \mathrm{ml} \mathrm{l}^{-1}\right)$ was injected into the incoming air stream and the concentration in the cabinet was adjusted to the desired level using electronic mass flow controllers (ASM; Bilthoven; The Netherlands). $\mathrm{H}_{2} \mathrm{~S}$ levels in the cabinets were monitored by an $\mathrm{SO}_{2}$ analyzer (model 9850) equipped with a $\mathrm{H}_{2} \mathrm{~S}$ converter (model 8770; Monitor Labs; Measurements Controls Corporation; Englewood; CO; USA). Sealing of the lid of the boxes and plant sets prevented absorption of $\mathrm{H}_{2} \mathrm{~S}$ by the nutrient solutions.

In the first experiment, plants were harvested after 10 days of exposure. In the second experiment after 7 days of exposure per treatment, sets of 4 plants were weighted (viz., total biomass was determined). Subsequently, each plant set was transferred to a separate vessel containing 1.11 of a similar 50\% Hoagland nutrient solution as the set was grown on before (Supplementary Fig. S1). Vessels with plant sets were placed in the stainless-steel cabinets described above (with similar $\mathrm{H}_{2} \mathrm{~S}$ levels) and plants were grown for an additional 3 days before harvest.

\section{Growth analyses}

Plant harvesting took place $3 \mathrm{~h}$ after the onset of the light period. To remove ions and other particles attached to the root, plants were placed with their roots in ice-cold de-mineralized water $(3 \times 20 \mathrm{~s})$. Thereafter, the root and shoot were separated and weighted. In the second experiment, the shoot was additionally separated in leaf blades and the whorl of leaf sheaths (viz., the seedlings did not yet possess a true stem, since all leaves emerged from the shoot base). Moreover, the total leaf blade area (abaxial plus adaxial) of the plants was determined by drawing the outlines of all leaf blades on graph paper.

\section{Stomatal resistance}

On the harvest day, stomatal resistance was analyzed at the abaxial and adaxial side of nascent leaf blades using a portable leaf porometer (AP4 Leaf Porometer; Delta-T-Devices Ltd.; Cambridge; UK). Measurements were performed 2-3 h after the onset of the light period.

\section{Plant sulfur status}

In whole shoots (leaf blades plus sheaths) and roots, which were stored at $-20{ }^{\circ} \mathrm{C}$ after harvest, sulfate levels were determined via high-performance liquid chromatography
(HPLC) following Maas et al. (1986). Additionally, watersoluble non-protein thiols were extracted from freshly harvested shoots and roots. The total water-soluble non-protein thiol and cysteine content were determined colorimetrically according to De Kok et al. (1988).

\section{Stomatal density}

For the determination of stomatal density, silicone impression paste was prepared by 1:1 mixing of catalyst and base material (Provil Novo Light; Kulzer GmbH; Hanau; Germany). Subsequently, freshly harvested nascent leaf blades were gently pressed in the paste with either their abaxial or adaxial side. Once the paste had solidified, the leaf blades were removed and the mould was filled with transparent nail polish, as described by Kraaij and van der Kooi (2020). The positive (nail polish) replica was next examined under an Olympus CX-41 microscope and photographed using a Euromex CMEX 5000 camera with ImageFocus v3.0 software. From the obtained photographs, stomatal density (number of stomata per leaf area) was determined. Importantly, during trial experiments, also leaf sheaths were examined, but these did not hold stomata.

\section{Transpiration rate}

The transpiration rate of plants, expressed on a whole plant fresh weight basis, was calculated over the 3-day period that plants were grown on the vessels as follows:

$I_{\mathrm{t}}=I \mathrm{u}-I \mathrm{~g}$

$I_{\mathrm{u}}=\left(\frac{\left(\ln P_{2}-\ln P_{1}\right)}{3}\right) \cdot\left(\frac{\left(I_{\mathrm{m} 2}-I_{\mathrm{m} 1}-8.95\right)}{\left(P_{2}-P_{1}\right)}\right)$

$I_{\mathrm{g}}=\left(\frac{\left(\ln S_{2}-\ln S_{1}\right)}{3}\right) \cdot 0.9+\left(\frac{\left(\ln R_{2}-\ln R_{1}\right)}{3}\right) \cdot 0.95$

where $I_{\mathrm{t}}$ represents the transpiration rate, $I_{\mathrm{u}}$ the water uptake rate, and $I_{\mathrm{g}}$ the amount of water required for plant growth (all expressed as $\mathrm{g} \mathrm{H}_{2} \mathrm{O} \mathrm{g}^{-1} \mathrm{FW}$ plant day ${ }^{-1}$ ). Furthermore, $P$ represents the whole plant's fresh weight, $S$ the shoot's fresh weight, $R$ the root's fresh weight, and $I_{\mathrm{m}}$ the total solution weight in the vessels, with the subscripts 1 and 2 denoting the parameters' value at the start and at the end of the 3-day exposure period, respectively. Moreover, whereas the factor 3 in the formulas refers to the 3-day duration of the experiment, the factor 8.95 refers to the average difference in solution weight of 4 vessels, which did not hold a plant set, between the start and end of the 3-day exposure period, respectively (standard deviation of this measurement was 0.61). Finally, the factors 0.9 and 0.95 represent the fraction 
Table 1 Biomass of maize as affected by various levels of atmospheric $\mathrm{H}_{2} \mathrm{~S}$ and sulfate deprivation. 10-day old maize was grown on a $50 \%$ Hoagland nutrient solution, containing $0(-\mathrm{S})$ or $1.0 \mathrm{mM}$ sulfate $(+\mathrm{S})$ and simultaneously fumigated with $0,0.5,1.0$, and $1.5 \mu \mathrm{l} \mathrm{l}^{-1}$
$\mathrm{H}_{2} \mathrm{~S}$ for 10 days. Data (g FW) represent the mean $( \pm \mathrm{SD})$ of 5 measurements with 6 plants in each and different letters indicate significant differences between treatments $(P \leq 0.05$; two-way ANOVA; Tukey's HSD test as a post hoc test)

\begin{tabular}{|c|c|c|c|c|c|c|c|c|}
\hline & \multicolumn{2}{|l|}{$0 \mu \mathrm{ll}^{-1} \mathrm{H}_{2} \mathrm{~S}$} & \multicolumn{2}{|l|}{$0.5 \mu \mathrm{l}^{-1} \mathrm{H}_{2} \mathrm{~S}$} & \multicolumn{2}{|c|}{$1.0 \mu \mathrm{l} \mathrm{l}^{-1} \mathrm{H}_{2} \mathrm{~S}$} & \multicolumn{2}{|l|}{$1.5 \mu \mathrm{l} \mathrm{l}^{-1} \mathrm{H}_{2} \mathrm{~S}$} \\
\hline & $+\mathrm{S}$ & $-S$ & $+\mathrm{S}$ & $-S$ & $+\mathrm{S}$ & $-S$ & $+\mathrm{S}$ & $-S$ \\
\hline Plant & $3.60 \pm 0.12 \mathrm{a}$ & $2.31 \pm 0.17 b$ & $3.78 \pm 0.15 a$ & $3.66 \pm 0.06 \mathrm{a}$ & $3.71 \pm 0.07 \mathrm{a}$ & $3.63 \pm 0.11 \mathrm{a}$ & $1.74 \pm 0.15 c$ & $1.77 \pm 0.08 \mathrm{c}$ \\
\hline Roots & $1.30 \pm 0.12 \mathrm{a}$ & $0.87 \pm 0.06 b$ & $1.39 \pm 0.08 \mathrm{a}$ & $1.33 \pm 0.05 \mathrm{a}$ & $1.36 \pm 0.06 \mathrm{a}$ & $1.33 \pm 0.05 \mathrm{a}$ & $0.96 \pm 0.09 b$ & $0.96 \pm 0.05 b$ \\
\hline Shoots & $2.30 \pm 0.08 \mathrm{a}$ & $1.45 \pm 0.17 b$ & $2.39 \pm 0.11 \mathrm{a}$ & $2.33 \pm 0.04 a$ & $2.35 \pm 0.11 \mathrm{a}$ & $2.30 \pm 0.08 \mathrm{a}$ & $0.78 \pm 0.08 c$ & $0.81 \pm 0.04 \mathrm{c}$ \\
\hline
\end{tabular}

of a maize shoot and root consisting of water, respectively (Ausma et al. 2017). It deserves mentioning that during the 3-day exposure period, the proportion of biomass allocated to the different plant organs was not affected.

\section{Statistics}

Statistical analyses were performed in GraphPad Prism (version 8.4.1; GraphPad Software; San Diego; CA; USA). Treatment means were compared using a two-way analysis of variance (ANOVA) with a Tukey's HSD test as post hoc test at the $P \leq 0.05$ level.

\section{Results and discussion}

To test the relevance of $\mathrm{H}_{2} \mathrm{~S}$ for the regulation of stomatal aperture, maize seedlings were grown with atmospheric $\mathrm{H}_{2} \mathrm{~S}$ in the presence or absence of sulfate in the root environment.

We first assessed what $\mathrm{H}_{2} \mathrm{~S}$ level is subtoxic for maize, albeit sufficiently high to fully cover the plant's sulfur demand for growth. Sulfur-deficiency symptoms manifested after 10 days of sulfur deprivation (Table 1). The biomass of sulfate-deprived seedlings was on average $36 \%$ lower than that of sulfate-sufficient seedlings, which could be ascribed to both a lower root $(33 \%)$ and shoot (37\%) biomass (Table 1).

$\mathrm{H}_{2} \mathrm{~S}$ fumigation can alleviate sulfur-deficiency symptoms. If maize was $\mathrm{H}_{2} \mathrm{~S}$ fumigated in the absence of a sulfate supply, the plants did not develop any sulfur-deficiency symptoms (Table 1). The biomass of sulfate-deprived plants that were fumigated with 0.5 or $1.0 \mu \mathrm{ll}^{-1} \mathrm{H}_{2} \mathrm{~S}$ was comparable to that of sulfate-sufficient, non-fumigated plants (Table 1), meaning that, analogous to the many plant species tested previously (Ausma et al. 2017; Ausma and De Kok 2019), maize can use $\mathrm{H}_{2} \mathrm{~S}$ as a sulfur source. The results further demonstrate that maize is rather insusceptible for the potential phytotoxicity of $\mathrm{H}_{2} \mathrm{~S}$. Only exposure to $1.5 \mu \mathrm{l}^{-1} \mathrm{H}_{2} \mathrm{~S}$ negatively affected plant growth (Table 1). Generally, monocots are highly $\mathrm{H}_{2} \mathrm{~S}$ tolerant (Stulen et al. 1990, 2000). In
Table 2 Biomass of maize as affected by $\mathrm{H}_{2} \mathrm{~S}$ fumigation and sulfate deprivation. 10-day old maize was grown on a 50\% Hoagland nutrient solution, containing $0(-\mathrm{S})$ or $1.0 \mathrm{mM}$ sulfate $(+\mathrm{S})$ and simultaneously fumigated with 0 or $1.0 \mu \mathrm{l}^{-1} \mathrm{H}_{2} \mathrm{~S}$ for 10 days. Data (g FW) represent the mean $( \pm$ SD) of 10 measurements with 4 plants in each and different letters indicate significant differences between treatments $(P \leq 0.05$; two-way ANOVA; Tukey's HSD test as a post hoc test)

\begin{tabular}{lllll}
\hline & $0 \mu \mathrm{l}^{-1} \mathrm{H}_{2} \mathrm{~S}$ & & $1.0 \mu 1^{-1} \mathrm{H}_{2} \mathrm{~S}$ \\
\cline { 2 - 3 } \cline { 5 - 5 } & $+\mathrm{S}$ & $-\mathrm{S}$ & $+\mathrm{S}$ & $-\mathrm{S}$ \\
\hline Plant & $3.46 \pm 0.11 \mathrm{a}$ & $2.57 \pm 0.10 \mathrm{~b}$ & $3.55 \pm 0.23 \mathrm{a}$ & $3.42 \pm 0.19 \mathrm{a}$ \\
Roots & $1.32 \pm 0.11 \mathrm{a}$ & $0.87 \pm 0.08 \mathrm{~b}$ & $1.41 \pm 0.14 \mathrm{a}$ & $1.29 \pm 0.14 \mathrm{a}$ \\
$\begin{array}{c}\text { Leaf } \\
\text { sheaths } \\
\begin{array}{c}\text { Leaf } \\
\text { blades }\end{array}\end{array}$ & $1.90 \pm 0.08 \mathrm{a}$ & $1.49 \pm 0.06 \mathrm{~b}$ & $1.92 \pm 0.12 \mathrm{a}$ & $1.90 \pm 0.09 \mathrm{a}$ \\
\hline
\end{tabular}

monocots, the shoot's meristem is sheltered by the whorl of leaves. Therefore, $\mathrm{H}_{2} \mathrm{~S}$ can hardly penetrate the meristem, which may explain why grasses are relatively $\mathrm{H}_{2} \mathrm{~S}$ insusceptible (Stulen et al. 1990, 2000).

Tissue $\mathrm{H}_{2} \mathrm{~S}$, cysteine, and glutathione levels may be more profoundly affected at higher $\mathrm{H}_{2} \mathrm{~S}$ levels (Birke et al. 2012; Ausma and De Kok 2019). Thus, in a second experiment, plants were fumigated with $1.0 \mu \mathrm{l} \mathrm{l}^{-1} \mathrm{H}_{2} \mathrm{~S}$ instead of $0.5 \mu \mathrm{l}^{-1} \mathrm{H}_{2} \mathrm{~S}$. Similar to our previous observations (Table 1), sulfate-deprived plants had a lower biomass than sulfate-sufficient plants, owing to a lower root (34\%) and leaf sheath biomass (22\%; Table 2). Leaf blade biomass was comparable between sulfate-sufficient and sulfate-deprived plants (Table 2).

Sulfate deprivation lowered tissue sulfate and (watersoluble non-protein) thiol levels. Whereas a 10-day sulfate deprivation of maize reduced shoot and root sulfate levels by $92 \%$ and $75 \%$, respectively, it reduced shoot and root thiol levels by $73 \%$ and $60 \%$, respectively (Fig. 1). In plants, the thiol pool is mainly comprised of glutathione, though cysteine is a minor thiol (Buwalda et al. 1993). In maize, cysteine accounted for only $12 \%$ and $16 \%$ of the shoot and root thiol pool, respectively (Fig. 1). Sulfate deprivation decreased tissue cysteine contents: it lowered root and shoot 

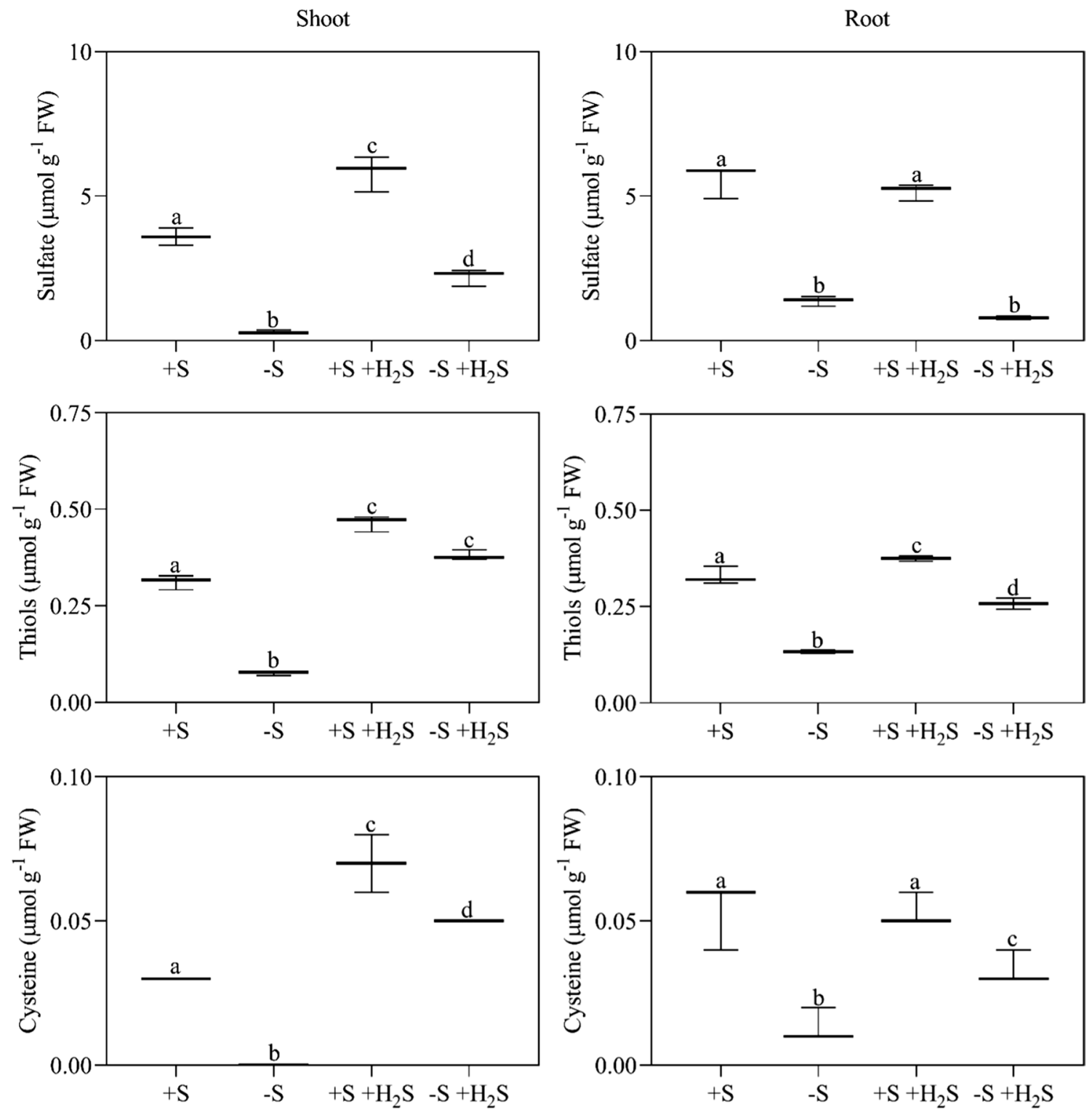

Fig. 1 The content of sulfate, total water-soluble non-protein thiols, and cysteine in maize as affected by $\mathrm{H}_{2} \mathrm{~S}$ fumigation and sulfate deprivation. For experimental details, see the legend of Table 2. Data, representing 3 measurements with 4 plants in each, are presented

as boxes with a 5-95 percentile and whiskers. Different letters indicate significant differences between treatments $(P \leq 0.05$; two-way ANOVA; Tukey's HSD test as a post hoc test)

cysteine content by $79 \%$ and $100 \%$, respectively (Fig. 1). Clearly, the lower biomass production upon sulfate deprivation was accompanied by lower sulfate, glutathione, and cysteine contents (Fig. 1).

The biomass of plants that were fumigated with $1.0 \mu \mathrm{l}^{-1}$ $\mathrm{H}_{2} \mathrm{~S}$ was comparable to that of sulfate-sufficient nonfumigated plants (Table 2). Thiol levels were higher in $\mathrm{H}_{2} \mathrm{~S}$-fumigated plants compared to non-fumigated plants (Fig. 1). Under sulfate-sufficient conditions, shoot total water-soluble non-protein thiol and cysteine levels were 1.4- and 2.0-fold higher in fumigated plants compared to non-fumigated plants, respectively (Fig. 1). Moreover,

under sulfate-deprived conditions, fumigated plants had a 5.0-fold higher shoot total water-soluble non-protein thiol level, a 1.9-fold higher root water-soluble non-protein thiol level, and a 3.0-fold higher root cysteine level compared to non-fumigated plants (Fig. 1). Shoot cysteine levels in sulfate-deprived fumigated plants were even 1.5 -fold higher compared to sulfate-sufficient non-fumigated plants (Fig. 1). Apparently, absorbed $\mathrm{H}_{2} \mathrm{~S}$ was metabolized with high affinity into cysteine and subsequently into glutathione.

$\mathrm{H}_{2} \mathrm{~S}$-fumigated plants additionally had a higher shoot sulfate content compared to non-fumigated plants (Fig. 1). Whereas sulfate-sufficient fumigated plants had a 1.5 -fold 
higher shoot sulfate content compared to sulfate-sufficient non-fumigated plants, sulfate-deprived fumigated plants had a 5.0-fold higher shoot sulfate content compared to sulfatedeprived non-fumigated plants (Fig. 1). The higher sulfate content in fumigated plants might be related to the oxidation of absorbed $\mathrm{H}_{2} \mathrm{~S}$ and/or the degradation of excessively accumulated organic compounds (Ausma and De Kok 2019). However, it may also be due to $\mathrm{H}_{2} \mathrm{~S}$ absorbance only partially downregulating root sulfate uptake (Ausma and De Kok 2019). Further research should elucidate the source of the accumulated sulfate.

Exposure of maize to $1.0 \mu \mathrm{l}^{-1} \mathrm{H}_{2} \mathrm{~S}$ did not affect the total leaf blade area and stomatal density at the abaxial and adaxial side of nascent leaves (Figs. 2 and 3). There were approximately 75 stomata $\mathrm{mm}^{-2}$ at the adaxial leaf side and

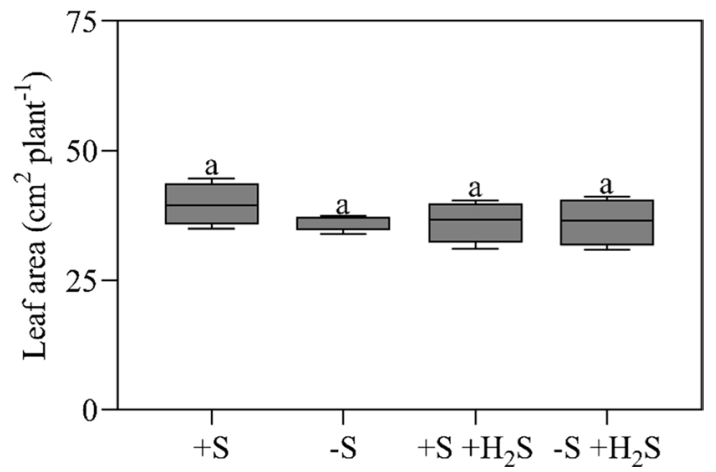

Fig. 2 Total leaf blade area of maize as affected by $\mathrm{H}_{2} \mathrm{~S}$ fumigation and sulfate deprivation. For experimental details, see the legend of Table 2. Data, representing 4 measurements with 4 plants in each, are presented as boxes with a 5-95 percentile and whiskers. Different letters indicate significant differences between treatments $(P \leq 0.05$; two-way ANOVA; Tukey's HSD test as a post hoc test)
50 at the abaxial leaf side (Fig. 3). Similar densities were reported previously (e.g., Zheng et al. 2013). Based on these observations, it is concluded that $\mathrm{H}_{2} \mathrm{~S}$ fumigation does not affect the total number of stomata per plant.

Based on these observations, it is also concluded that it is unlikely that $\mathrm{H}_{2} \mathrm{~S}$ regulates the formation of aerenchyma in maize leaves. Aerenchyma can be formed via programmed cell death (PCD) events and $\mathrm{H}_{2} \mathrm{~S}$ is hypothesized to be a signal molecule stimulating PCD (Maniou et al. 2014). However, $\mathrm{H}_{2} \mathrm{~S}$ fumigation did neither alter leaf biomass nor leaf area (Figs. 2 and 3). It did thus not affect the specific leaf weight, which implies $\mathrm{H}_{2} \mathrm{~S}$ did not induce aerenchyma formation in the foliage. In accordance with this result, previously, it was shown that exposure of maize to atmospheric $\mathrm{H}_{2} \mathrm{~S}$ did not trigger the aerenchyma formation in roots (Ausma et al. 2017).

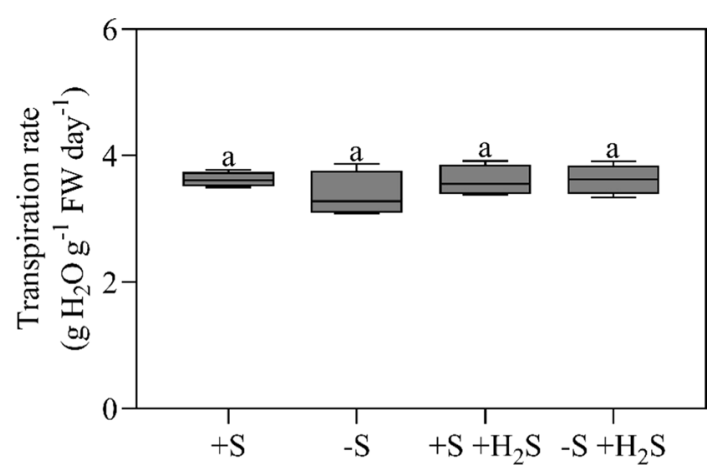

Fig. 4 Transpiration rate of maize as affected by $\mathrm{H}_{2} \mathrm{~S}$ fumigation and sulfate deprivation. For experimental details, see the legend of Table 2. Data, representing 4 measurements with 4 plants in each, are presented as boxes with a 5-95 percentile and whiskers. Different letters indicate significant differences between treatments $(P \leq 0.05$; two-way ANOVA; Tukey's HSD test as a post hoc test)
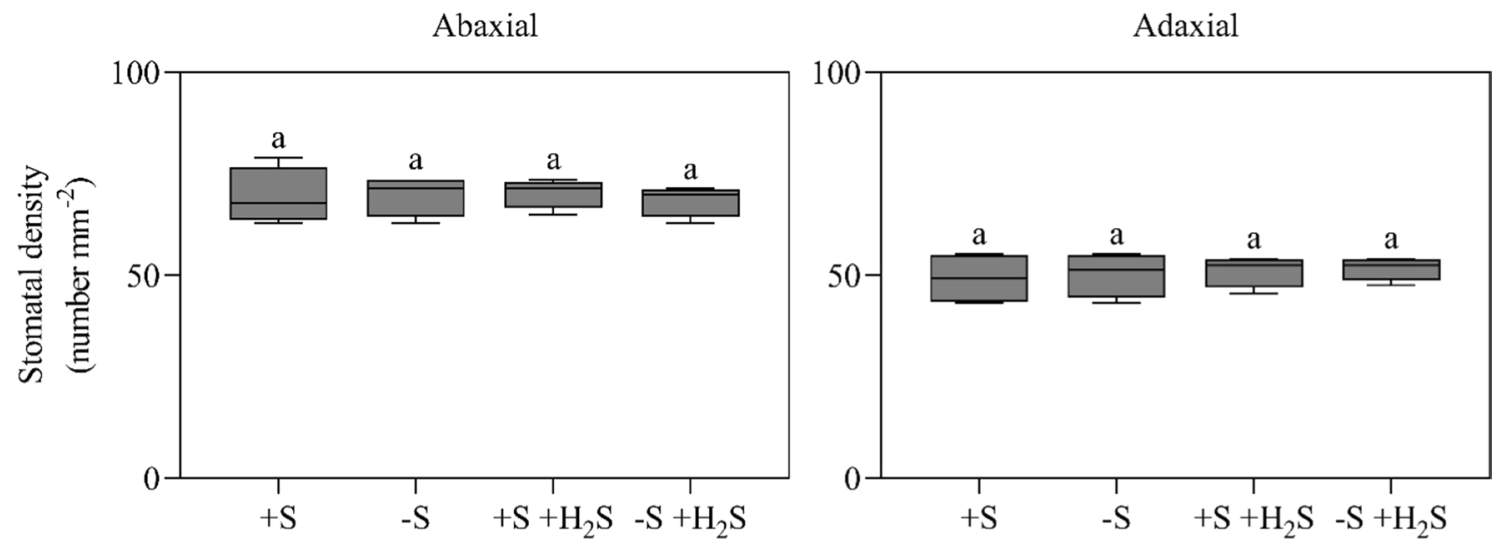

Fig. 3 Stomatal density at the abaxial and adaxial side of leaf blades of maize as affected by $\mathrm{H}_{2} \mathrm{~S}$ fumigation and sulfate deprivation. For experimental details, see the legend of Table 2. Data, representing 4 measurements with 2 plants in each, are presented as boxes with

a 5-95 percentile and whiskers. Different letters indicate significant differences between treatments $(P \leq 0.05$; two-way ANOVA; Tukey's HSD test as a post hoc test) 


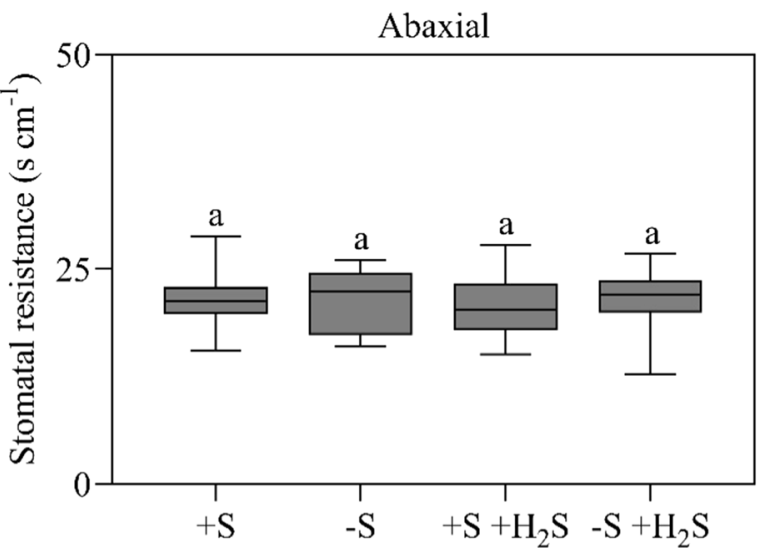

Fig. 5 Stomatal resistance at the abaxial and adaxial side of leaf blades of maize as affected by $\mathrm{H}_{2} \mathrm{~S}$ fumigation and sulfate deprivation. For experimental details, see the legend of Table 2. Data, representing 18 measurements on different plants, are presented as boxes

Apart from having no effect on the total number of stomata per plant, exposure to $1.0 \mu \mathrm{l} \mathrm{l}^{-1} \mathrm{H}_{2} \mathrm{~S}$ did not affect the plants' transpiration rate (Fig. 4). Transpiration rates were approximately $3.6 \mathrm{~g} \mathrm{H}_{2} \mathrm{O} \mathrm{g}^{-1} \mathrm{FW}$ plant day ${ }^{-1}$ (Fig. 4). Accordingly, $\mathrm{H}_{2} \mathrm{~S}$ exposure did not affect stomatal resistance at the abaxial and adaxial side of nascent leaves (Fig. 5). Since $\mathrm{H}_{2} \mathrm{~S}$ fumigation did neither affect the total number of stomata per plant nor the plant's transpiration rate and stomatal resistance, we conclude that fumigation did not affect the transpiration rate per stoma.

In maize and other plants, stomatal transpiration and conductance are strongly positively correlated with stomatal aperture (Shimshi 1963; Shimshi and Ephrat 1975; Lawson et al. 1998; Kaiser 2009). For instance, Shimshi (1963) reported for maize that stomatal conductance $(y)$ depends on aperture $(x)$ according to the formula $y=0.073+0.147 x$ $\left(R^{2}=0.88\right)$. It thus is safe to say that fumigation with $1.0 \mu \mathrm{l}^{-1} \mathrm{H}_{2} \mathrm{~S}$ of maize did not modify stomatal aperture. The absence of an effect is not caused by $\mathrm{H}_{2} \mathrm{~S}$ levels that are too low, because shoot cysteine levels were two-to-threefold higher in $\mathrm{H}_{2} \mathrm{~S}$-fumigated plants compared to non-fumigated plants (Fig. 1), which is highly similar to the twofold increase of foliar cysteine levels that Batool et al. (2018) reported to strongly impact stomatal aperture. Clearly, at least in maize, $\mathrm{H}_{2} \mathrm{~S}$ does not interfere with the signal transduction cascade that regulates stomatal aperture.

\section{Conclusion}

Maize plants could use atmospheric $\mathrm{H}_{2} \mathrm{~S}$ as a sulfur source for growth. Foliar $\mathrm{H}_{2} \mathrm{~S}$ absorbance markedly affected the plant's sulfur status; however, it did not affect the total leaf area, stomatal density, stomatal resistance, and transpiration

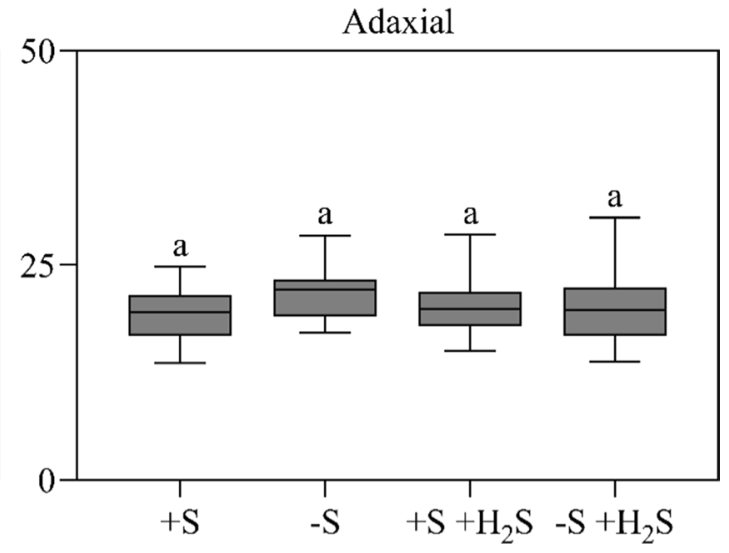

with a 5-95 percentile and whiskers. Different letters indicate significant differences between treatments $(P \leq 0.05$; two-way ANOVA; Tukey's HSD test as a post hoc test)

rate of plants. We thus conclude that, at least in maize, $\mathrm{H}_{2} \mathrm{~S}$ does not function as signal molecule in the regulation of stomatal aperture.

Author contributions statement TA conceived and designed the study. TA, JM, and TRP collected the data. TA analyzed the data. TA, CJvdK, and LJDK wrote the manuscript.

Acknowledgements The research of TA and CJvdK is funded by The Netherlands Organization for Scientific Research (NWO) via ALW Graduate Program Grant 2017.015 and Veni Grant 016.181.025, respectively. Data for this study were obtained during JM's and TP's internships for their studies at the Van Hall Larenstein and Hanze University of Applied Sciences, respectively. The authors thank J. Theo M. Elzenga for critical reading of the manuscript.

Open Access This article is licensed under a Creative Commons Attribution 4.0 International License, which permits use, sharing, adaptation, distribution and reproduction in any medium or format, as long as you give appropriate credit to the original author(s) and the source, provide a link to the Creative Commons licence, and indicate if changes were made. The images or other third party material in this article are included in the article's Creative Commons licence, unless indicated otherwise in a credit line to the material. If material is not included in the article's Creative Commons licence and your intended use is not permitted by statutory regulation or exceeds the permitted use, you will need to obtain permission directly from the copyright holder. To view a copy of this licence, visit http://creativecommons.org/licenses/by/4.0/.

\section{References}

Aroca A, Gotor C, Romero LC (2018) Hydrogen sulfide signaling in plants: emerging roles of protein persulfidation. Front Plant Sci 9:1369. https://doi.org/10.3389/fpls.2018.01369 
Ausma T, De Kok LJ (2019) Atmospheric $\mathrm{H}_{2} \mathrm{~S}$ : impact on plant functioning. Front Plant Sci 10:743. https://doi.org/10.3389/ fpls.2019.00743

Ausma T, Parmar S, Hawkesford MJ, De Kok LJ (2017) Impact of atmospheric $\mathrm{H}_{2} \mathrm{~S}$, salinity and anoxia on sulfur metabolism in Zea mays. In: De Kok LJ, Hawkesford MJ, Haneklaus SH, Schnug E (eds) Sulfur metabolism in higher plants: fundamental, environmental and agricultural aspects, 1 st edn. Springer, Dordrecht, pp 93-101

Batool S, Uslu VV, Rajab H, Ahmad N, Waadt R, Geiger D, Malagoli M, Xiang CB, Hedrich R, Rennenberg H, Herschbach C, Hell R, Wirtz M (2018) Sulfate is incorporated into cysteine to trigger ABA production and stomatal closure. Plant Cell 30:2973-2987. https://doi.org/10.1105/tpc.18.00612

Beauchamp RO, Bus JS, Popp JA, Boreiko CJ, Andjelkovich DA (1984) A critical review of the literature on hydrogen sulfide toxicity. CRC Crit Rev Toxicol 13:25-97. https://doi.org/10.3109/10408 448409029321

Birke H, De Kok LJ, Wirtz M, Hell R (2015) The role of compartmentspecific cysteine synthesis for sulfur homeostasis during $\mathrm{H}_{2} \mathrm{~S}$ exposure in Arabidopsis. Plant Cell Physiol 56:358-367. https:// doi.org/10.1093/pcp/pcu166

Buchner P, Stuiver CEE, Westerman S, Wirtz M, Hell R, Hawkesford MJ, De Kok LJ (2004) Regulation of sulfate uptake and expression of sulfate transporter genes in Brassica oleracea L. as affected by atmospheric $\mathrm{H}_{2} \mathrm{~S}$ and pedospheric sulfate nutrition. Plant Physiol 136:3396-3408. https://doi.org/10.1104/pp.104.046441

Buwalda F, De Kok LJ, Stulen I (1993) Effects of atmospheric $\mathrm{H}_{2} \mathrm{~S}$ on thiol composition of crop plants. J Plant Physiol 142:281-285. https://doi.org/10.1016/S0176-1617(11)80423-2

Calderwood A, Kopriva S (2014) Hydrogen sulfide in plants: from dissipation of excess sulfur to signaling molecule. Nitric Ox 41:72-78. https://doi.org/10.1016/j.niox.2014.02.005

De Kok LJ, Buwalda F, Bosma W (1988) Determination of cysteine and its accumulation in spinach leaf tissue upon exposure to excess sulfur. J Plant Phys 133:502-505. https://doi.org/10.1016/ S0176-1617(88)80045-2

De Kok LJ, Stahl K, Rennenberg H (1989) Fluxes of atmospheric hydrogen sulfide to plant shoots. New Phytol 112:533-542. https ://doi.org/10.1111/j.1469-8137.1989.tb00348.x

De Kok LJ, Stuiver CEE, Rubinigg M, Westerman S, Grill D (1997) Impact of atmospheric sulfur deposition on sulfur metabolism in plants: $\mathrm{H}_{2} \mathrm{~S}$ as sulfur source for sulfur deprived Brassica oleracea L. Bot Acta 110:411-419. https://doi. org/10.1111/j.1438-8677.1997.tb00657.x

Hancock JT (2018) Hydrogen sulfide and environmental stresses. Environ Exp Bot 161:50-56. https://doi.org/10.1016/j.envex pbot.2018.08.034

Hawkesford MJ, De Kok LJ (2006) Managing sulphur metabolism in plants. Plant Cell Environ 29:382-395. https://doi.org/10.111 1/j.1365-3040.2005.01470.x

Honda K, Yamada N, Yoshida R, Ihara H, Sawa T, Akaike T, Iwai S (2015) 8-mercapto-cyclic GMP mediates hydrogen sulfideinduced stomatal closure in Arabidopsis. Plant Cell Physiol 56:148-1489. https://doi.org/10.1093/pcp/pcv069

Kaiser H (2009) The relation between stomatal aperture and gas exchange under consideration of pore geometry and diffusional resistance in the mesophyll. Plant Cell Environ 32:1091-1098. https://doi.org/10.1111/j.1365-3040.2009.01990.x

Koralewska A, Posthumus FS, Stuiver CEE, Buchner P, De Kok LJ (2007) The characteristic high sulfate content in Brassica oleracea is controlled by the expression and activity of sulfate transporters. Plant Biol 9:654-661. https://doi.org/10.1055/s-2007-965438

Koralewska A, Stuiver CEE, Posthumus FS, Kopriva S, Hawkesford MJ, De Kok LJ (2008) Regulation of sulfate uptake, expression of the sulfate transporters Sultr 1;1 and Sultr1;2, and APS reductase in Chinese cabbage (Brassica pekinensis) as affected by atmospheric $\mathrm{H}_{2} \mathrm{~S}$ nutrition and sulfate deprivation. Funct Plant Biol 35:318-327. https://doi.org/10.1071/FP07283

Kraaij M, van der Kooi CJ (2020) Surprising absence of association between flower surface microstructure and pollination system. Plant Biol 22:177-183. https://doi.org/10.1111/plb.13071

Lawson T, James W, Weyers J (1998) A surrogate measure of stomatal aperture. J Exp Bot 49:1397-1403. https://doi.org/10.1093/ $\mathrm{jxb} / 49.325 .1397$

Lee ZW, Zhou J, Chen CS, Zhao Y, Tan CH, Li L, Moore PK, Deng LW (2011) The slow-releasing hydrogen sulfide donor, GYY4137, exhibits novel anti-cancer effects in vitro and in vivo. PLoS ONE 6:e21077. https://doi.org/10.1371/journal.pone.0021077

Li ZG, Min X, Zhou ZH (2016) Hydrogen sulfide: a signal molecule in plant cross-adaptation. Front Plant Sci 26:1621. https://doi. org/10.3389/fpls.2016.01621

Lisjak M, Srivastava N, Teklic T, Civale L, Lewandowski K, Wilson I, Wood ME, Whiteman M, Hancock JT (2010) A novel hydrogen sulfide donor causes stomatal opening and reduces nitric oxide accumulation. Plant Physiol Biochem 48:931-935. https://doi. org/10.1016/j.plaphy.2010.09.016

Lisjak M, Teklic T, Wilson I, Wood M, Whiteman M, Hancock JT (2011) Hydrogen sulfide effects on stomatal apertures. Plant Signal Behav 6:1444-1446. https://doi.org/10.4161/psb.6.10.17104

Maas FM, De Kok LJ (1988) In vitro NADH oxidation as an early indicator for growth reductions in spinach exposed to $\mathrm{H}_{2} \mathrm{~S}$ in the ambient air. Plant Cell Physiol 29:23-526. https://doi.org/10.1093/ oxfordjournals.pcp.a077524

Maas FM, Hoffmann I, Van Harmelen MJ, De Kok LJ (1986) Refractometric determination of sulfate and anions in plants separated by high performance liquid chromatography. Plant Soil 91:129-132

Maniou F, Chorianopoulou S, Bouranis DL (2014) New insights into trophic aerenchyma formation strategy in maize (Zea mays L.) organs during sulfate deprivation. Front Plant Sci 5:581. https:// doi.org/10.3389/fpls.2014.00581

Noble D (2013) Physiology is rocking the foundations of evolutionary biology. Exp Physiol 98:1235-1243. https://doi.org/10.1113/ expphysiol.2012.071134

Noble D, Jablonka E, Joyner M, Müller GB, Omholt SW (2014) Evolution evolves: physiology returns to centre stage. J Physiol 592:2237-2244. https://doi.org/10.1113/jphysiol.2014.273151

Piersma T, Van Gils JA (2011) The flexible phenotype: a body-centred integration of ecology, physiology, and behaviour. Oxford University Press, Oxford

Rajab H, Sayyar Khan M, Malagoli M, Hell R, Wirtz M (2019) Sulfate-induced stomata closure requires the canonical ABA signal transduction machinery. Plants 8:21. https://doi.org/10.3390/plant s8010021

Riahi S, Rowley CN (2014) Why can sulfide permeate cell membranes? J Am Chem Soc 136:15111-15113. https://doi.org/10.1021/ja508 $063 \mathrm{~s}$

Scuffi D, Alvarez C, Laspina N, Gotor C, Lamattina L, Garcia-Mata C (2014) Hydrogen sulfide generated by L-cysteine desulfhydrase acts upstream of nitric oxide to modulate abscisic acid-dependent stomatal closure. Plant Phys 166:2065-2076. https://doi. org/10.1104/pp.114.245373

Shimshi D (1963) Effects of soil moisture and phenylmercuric acetate upon stomatal aperture, transpiration, and photosynthesis. Plant Phys 38:713-721. https://doi.org/10.1104/pp.38.6.713

Shimshi D, Ephrat J (1975) Stomatal behavior of wheat cultivars in relation to their transpiration, photosynthesis, and yield. J Agron 67:326-331. https://doi.org/10.2134/agronj1975.0002196200 $6700030011 \mathrm{x}$

Sirko A, Gotor C (2007) Molecular links between metals in the environment and plant sulfur metabolism. In: Hawkesford MJ, De 
Kok LJ (eds) Sulfur in plants an ecological perspective, 1st edn. Springer, Berlin, pp 169-195

Stuiver CEE, De Kok LJ (2001) Atmospheric $\mathrm{H}_{2} \mathrm{~S}$ as sulfur source for Brassica oleracea: kinetics of $\mathrm{H}_{2} \mathrm{~S}$ uptake and activity of $O$-acetylserine (thiol)lyase as affected by sulfur nutrition. Environ Exp Bot 46:29-36. https://doi.org/10.1016/S0098-8472(01)00080-6

Stulen I, Posthumus FS, Amâncio S, De Kok LJ (1990) Why is $\mathrm{H}_{2} \mathrm{~S}$ not phytotoxic in monocots? Physiol Plant 7:123

Stulen I, Posthumus FS, Amâncio S, Masselink-Beltman I, Müller M, De Kok LJ (2000) Mechanism of $\mathrm{H}_{2} \mathrm{~S}$ phytotoxicity. In: Brunold C, Rennenberg H, De Kok LJ, Stulen I, Davidian JC (eds) Sulfur nutrition and sulfur assimilation in higher plants: molecular, biochemical and physiological aspects, 1st edn. Paul Haupt, Bern, pp 381-383

Tausz M, Van der Kooij TAW, Müller M, De Kok LJ, Grill D (1998) Uptake and metabolism of oxidized and reduced sulfur pollutants by spruce trees. In: De Kok LJ, Stulen I (eds) Responses of plant metabolism to air pollution and global change, 1st edn. Backhuys Publishers, Leiden, pp 457-460

Van der Kooij TAW, De Kok LJ (1998) Kinetics of deposition of $\mathrm{SO}_{2}$ and $\mathrm{H}_{2} \mathrm{~S}$ to shoots of Arabidopsis thaliana. In: De Kok LJ, Stulen I (eds) Responses of plant metabolism to air pollution and global change, 1st edn. Backhuys Publishers, Leiden, pp 479-481

Zhang J, Zhou M, Ge Z, Shen J, Zhou C, Gotor C, Romero LC, Duan X (2019) ABA-triggered guard cell L-cysteine desulfhydrase function and in situ $\mathrm{H}_{2} \mathrm{~S}$ production contributes to heme oxygenase-modulated stomatal closure. Plant Cell Environ. https://doi. org/10.1111/pce. 13685

Publisher's Note Springer Nature remains neutral with regard to jurisdictional claims in published maps and institutional affiliations. 